\title{
MANAGERIAL DISCOURSE IN FINANCIAL COMMUNICATION
}

\section{Rasakumaran.A}

* Senior Lecturer in English Language Teaching University of Jaffna, Sri Lanka rasakumaran1957@gmail.com

\begin{abstract}
Company executives often play the role of spokesperson for their companies and their discourses have become a recurring object of study. As such managerial discourse, be it written or spoken is considered as a management tool. This article attempts to identify, describe and understand the function of the managerial discourse as expressed in the letters of presentation of the financial statements of two popular companies in Sri Lanka between 2012 and 2016. The lexical identification of the statements formed the basis for the analysis of the discourse that was present in the letters exchanged among executives. The results of the analysis revealed that the executives of these two companies tried their maximum to exert influence on those who read the letters. It was also revealed that two important dimensions of managerial discourse were employed: strategic, which created a desirable image of their companies and marketing, where they tried to promote their company as a product.
\end{abstract}

Key words: managerial speech, accounting, discourse analysis, strategic, marketing

\subsection{Introduction}

For the last few decades, many companies have suffered from various crises of credibility due to the processes of democratization, the empowerment of individuals and social groups, and the evolution of communication techniques. The last one has been a determining factor in the formation of different social movements. Therefore, companies have been forced to create different communication strategies, which seek the approval of the different power groups that participate in their social environment.

Accounting, as a scientific discipline (Sürmen \& Daştan, 2014), was born as a social need to measure economic reality by quantifying the transactions carried out by organizations. As time has passed, it has been adapted to the new information needs of users of accounting information; for instance, the incorporation of fair value as a measurement method (Devi, Devi, Kumar, \& Taylor, 2012). However, company managers have understood that quantitative information is not sufficient to communicate their results as a social entity, but it is also important to incorporate qualitative aspects.

Each year the companies present their financial statements in order to communicate the results obtained during that period to facilitate the decision making of the different users, be they internal or external, of the accounting information. These reports are published 
in the form of an annual report that begins with a cover letter, signed by the board of directors or directors of the respective companies.

The objective of this paper is to identify, describe and understand the role of managerial discourse expressed in the letter of presentation of the Financial Statements of two popular companies in Sri Lanka between 2012 and 2016. The number of companies included in this study was limited to two due to reasons beyond the control of the researcher. The researcher approached seven companies but all but the two were not willing to expose their correspondences related to financial statements even after the promise that their correspondences would only be used for purely academic purposes and their identities would remain anonymous. The companies that are part of the present investigation are dedicated to the production of commodities; the difference between them is that one is a state enterprise (a corporation, hereafter Company A), while the other is a private capital (hereafter Company B).

It is important to point out that the research carried out, essentially, is interested in the perspective of the persuasion of statements and not in the effects obtained. The significance of the content exists independently of the effects they have. The problem of reception is not part of this research.

\subsection{Materials and Methods}

The research data are collected from the statements of the letters of presentation of the annual financial statements of the companies issued between 2012 and 2016 . A transversal analysis of the discourse of the statements of the letters of presentation of financial statements, based on lexical identification (Lepsinger \& DeRosa, 2010) was employed. This analysis deals with the interactive and inter-subjective dimension of the use of language, through research and analysis of real data. It investigated the written language, beyond the limits of the sentence, establishing the relation between language and society (Hatch, 1992). The approach is interpretive, that is, it conceives the organization as a subjective world and is interested in the representations of the actors (Lämsä \& Sintonen, 2006). The discourse described in these letters is understood as a polyphony; in other words, it is not only interesting for its content, but also for the effect it seeks to produce, to construct reality socially (Berger \& Luckmann, 1967). All reality is represented by individuals or groups, reconstructed in their cognitive system, integrated into their value system, depending on their history and the social and ideological context they face (Simon, 2013).

The concept of discourse and influence are two strongly related concepts; talk is undoubtedly an exchange of information, but it is also an act governed by precise rules that seek to transform the situation of 
the receiver and modify his belief system and / or change his system of attitudes (Junhui, 2015). A discourse not only describes the preexisting reality, but also constructs the representation of reality that the speaker wishes to share with his interlocutor. In general, for most language specialists, the issuance of a discourse (oral or written) entails the intentionality of acting on others.

Companies seek to influence and control the organization through their speech and sensemaking (Weick, 1995). Communication is seen as the core of the organization and its environment through discursive practices; its members engage in the construction of a complex system with different meanings (Lämsä $\&$ Sintonen, 2006). In the same sense, Gorysberg \& Slind (2012) show that the evolution of organizational discourse is strongly structured by its context of enunciation, that is, for the content of a discourse to be communicable it is necessary to share certain cultural presumptions. Acts of language are influenced by the context in which the person who communicates, develops and also contributes to build relationship is a creator of a social reality. When he wants to share this relationship, he evaluates the speaker and of the functions or effects of the discourse in the said context (Teun, 1993). Similarly, Simon (2013) points out that discourse is a tool of co-construction of organizational identity.

The analysis of the data is performed according to an interpretive perspective, that is, the narrative is considered a reflection of the culture. For this reason, the carries out the analysis of written discourse, bearing in mind three dimensions implicit in it: social, cognitive and discursive. The understanding of written discourse is a psycho-discursive phenomenon and of a social as well as cognitive nature. In its social dimension, understanding constitutes a situated communicative activity. As for its cognitive nature, the comprehension of discourse is an intentional process of high complexity, conformed by a series of psycholinguistic processes, sustained both in lower-order cognitive processing: attention, perception and memory and Superior: decision making, monitoring, reflection, among others (Bhatia, 2004). The analysis is presented below.

\subsection{Social and Discursive Context of the Document}

Context is defined as the set of extra lingual conditions of production of a discursive situation and is decisive in understanding an utterance. Language acts must be understood in their context of enunciation. The mastery of the ability to speak and understand is fully manifested in writing, in the writing of discourse and in the understanding of writing; it is one of the relations that the researcher establishes between rhetoric and hermeneutics (Halliday \& Hasan , 1985; Malinowski, 1994; Manca, 2012) This context is analyzed from the point of view of social and discursive through the approach of three questions: who writes?, who is addressed?, what relationship is established? (SeeTable1). 
Table 1: Social and discursive dimension of letters

\begin{tabular}{|l|l|l|l|}
\hline $\begin{array}{l}\text { Investigation } \\
\text { questions }\end{array}$ & Social & discursive \\
\hline Who writes? & Announcer & Speaker & $\begin{array}{l}\text { Singular, Plural and } \\
\text { Neutral }\end{array}$ \\
\hline $\begin{array}{l}\text { Who is it addressed } \\
\text { to? }\end{array}$ & Receiver & Addressee & $\begin{array}{l}\text { Singular, Plural and } \\
\text { Neutral }\end{array}$ \\
\hline $\begin{array}{l}\text { What relationship is } \\
\text { established? }\end{array}$ & $\begin{array}{l}\text { Symmetrical and } \\
\text { Asymmetric }\end{array}$ & $\begin{array}{l}\text { Assertive, Interrogative, } \\
\text { Intimidation }\end{array}$ \\
\hline
\end{tabular}

Linguistic semiotics defines a speech act as a staging that puts in relation two spaces of meaning: external or situational, which is defined as the space occupied by those responsible for such acts and internal or discourse, which is defined as the place of the discursive instance (Levinson, 1983; Thomas, 2013). The social figure presupposes the existence of the discursive figure.

In the social dimension the figures of speaker and receiver are identified in a symmetrical / asymmetric relationship. Then, in the discursive dimension, the figure of the enunciator and addressee is identified in an assertive / interrogative / intimidating relationship. The enunciator mentally constructs the addressee who, in turn, establishes cognitive relations different from those established by the enunciator. Therefore, two different figures appear discursively: the target subject and the interpreting subject (Bruner, 1991).

\section{Analysis of communication}

Here the objective is to identify the argumentative structure, from the cognitive and discursive point of view, based on two questions: depending on what is communicated from what is communicated? The first question seeks to achieve the interpretative framework of the enunciator (presuppositions) and the second question the conception of reality from which it is communicated (see table 2).

Communication activities are performed according to the influences that the enunciator has received, in terms of oral or written "say" and the relationships he makes with other events or spaces of activity (Bruner, 1986). Then, they communicate from the (mental) conception of the different spaces of action that we possess or the conception of the action performed by other individuals, more so of the projection of said action. Finally, it is a particular way of representing certain events. 
Table 2: Analysis of communication

\begin{tabular}{|l|l|}
\hline Questions & Cognitive and discursive dimension \\
\hline Depending on what is communicated? & $\begin{array}{l}\text { Basic interpretative framework, } \\
\text { which allows the enunciator to pre- } \\
\text { suppose the facts. }\end{array}$ \\
\hline From what is communicated? & $\begin{array}{l}\text { Conception of the business environ- } \\
\text { ment and its relationship with it. }\end{array}$ \\
\hline
\end{tabular}

\section{Functions of communication}

Managers, in their capacity as representative of the organization, are a channel in front of the company and its environment. Through an act of communication (oral or written) they propose different ways to observe the environment and activities carried out by the company. An act of language is a product of psychosocial beings, that are more or less aware of the practices and imaginary representations of the community to which they belong and the subject, by producing an act of language, does so in order to influence on others (Johnson \& Johnson, 1999). The objective is to identify the role of the communication presented in the letters of presentation of the financial statements, how it is proposed to observe the business activity and what is the impact on its environment.

\subsection{Results and Discussion}

\section{Social and discursive context of the documents}

From the content analysis of the directory letters issued between the years 2012 and 2016 it is inferred that the predominant social figure as speaker is the chairman of the board, followed by the general manager. As stated in Company A's bylaws, the general manager has the powers that the board delegates and remains in office as long as he has the trust of this collegiate body. Between 2012 and 2016, two professionals were in the position of president of the board, both of them civil engineers. In addition, a commercial engineer and an economist, performed as general managers.

The enunciator figure is presented in plural form, predominantly through an 'us', followed by a singular presentation expressed as a self and a neutral presentation. The fact that the managers of Company A are presented preferably in a plural form expresses that in their discourse they assume a collective identity; that is, when communicating they include or evoke several people of the company. By using the plural 'we' the speaker creates an environment into which the listeners are also included and this encourages the listeners to become more committed. The letters read: "Among the main challenges we face in 2013 are ensuring adequate progress on structural projects ... In addition, we must continue to improve our competitiveness." (Financial Statement, 2013, Company A) 
In the case of Company B, the predominant social figure (speaker) is the chairman of the board, whose function is regulated by law. Between 2012 and 2016, the president - by profession industrial civil engineer - remained in his position. From the discursive point of view, the enunciator is preferably presented in the first person singular, I, who assumes an individual identity, that is, is presented in a subjective, sincere and intimate. The discursive self is constructed while it is being written and implies the identification with certain social discourses and often occurs implicitly (Castelló, Corcelles, Iñesta, Bañales \& Vega, 2011). From the organizational point of view, a committed manager is shown, who adheres to an institutional discourse. Failure to comply with workers' demands would eventually lead to the halting of work, lower production targets and increases in production costs.

Company A executives, through the statements in the letters of publication of the financial statements, show empathy with the demands of the workers, but also explain the efforts made by the company with the rest of the Sri Lankans to meet their demands. For this reason, good relations with them must be maintained in order to produce and thus deliver benefits to all Sri Lankans. For example, the letters read: "Being the Chairman of the Board of Directors of Company A, I have had the opportunity to know, from the first source, the most relevant information about the Corporation. Based on the above, I am convinced that the company has advanced in the right direction, that it has fulfilled its goals adding value and providing resources, and that, therefore, it belongs to all Sri Lankans and is more than justified."

It can be inferred from the polyphonic discourse theory (that) in discursive strategies the enunciator addresses the addressee employing plural terms personal pronoun 'you'. The year 2013 was an exception, where the figure that happens to predominate is the neutral. The neutral figure marks a distance from its addressee in the discursive point of view.

Undoubtedly, the directors of Company A and Company B in their roles of announcer and enunciator of the letters establish a context of interpretation of the financial statements from their statements. That is, if the speaker refers to a particular object, indirectly, he is exerting influence on his interlocutor. When people talk, they transmit information to interact with others; they are finally doing an action. In Brandom's words (2003) "a saying is a doing"; according to the researcher, certain statements are not simple affirmations, but actions.

In the case of the company $\mathrm{B}$, the speaker shareholders are addressed first and then the workers. The letters read: "The year 2012 presented a complex and challenging macroeconomic environment for Company B... The Sri Lankan economy performed relatively weak, considering the positive international environment, which, together with strong competition in some segments of the domestic market, negatively affected 
the Company's results" (Financial statement 2012, Company B). It can be deduced that the decline in the results of the company had an impact on the Sri Lankan economy, an external event that is beyond the control of the company. From the discursive point of view, the enunciator addresses a predominantly plural addressee, expressed in you, that is, he commits himself to the recipient figure. Also the figure of the recipient appears as neutral; in this case, the enunciator takes distance from the recipient, that is, does not get involved.

Power relations are part of an act of communication and reflect the degree of closeness or distance with the target audience on the basis of the type of relationship that the enunciator wishes to establish with the recipient. From the social point of view the power relation is established using language (symmetric) which shows equal responsibilities for both the speaker and the listener and from the point of view of discursive in terms assertive, interrogative or intimidating (asymmetric) terms are used. In the case of Company A, the chairman of the board or general manager preferably establishes a symmetrical relationship with its target audience (workers and Sri Lankans); from the discursive point of view, an assertive relationship is established, between enunciator and recipient.

An assertive discourse allows the enunciator to appear with certainty and authority, the above does not mean that the statements that appear in the letters represent the truth; nevertheless, they are offered with security and knowledge, using words that try to persuade the recipient about what is to say or what to do. The letters, read: "The main company of Sri Lanka must be leader in all aspects, for the good of Sri Lanka" (Financial statement 2013, Company A).

In Company B, the chairman of the board preferably establishes with the target audience (shareholders and workers) an asymmetrical relationship; from the discursive point of view, an assertive relationship is established, between enunciator and recipient. The letters read: "At the conclusion of this account I would like to thank all our customers and suppliers for their preference and loyalty; to all persons working in the Company for their commitment, dedication and effort in the fulfillment of their responsibilities; and finally, to our shareholders for the permanent trust placed in our institution."

\section{Analysis of communication}

Company A executives develop their message in terms of the business reality they have contributed to building, which is their collective memory (Bruner, 2002) since the contribution of this organization to national development is a theme that is installed in Sri Lankans society; Executives know this and explain it in the letters of communication of the financial statements, as phrases such as "Sri Lanka is optimistically looking forward to the future of Company A, which is closely linked to the future of Sri Lanka ." It is not Sri Lanka that realizes this presupposition, but the executives 
of Company A. Thus, we can affirm that the president of the board and / or general manager communicates according to the representations that they have of a public company like Company A, thus conforming its interpretative framework. This is complemented by the role of the managers of an organization, among others, to promote its image, as spokesperson, in relation to its environment and influence the environment through its discourse to obtain long-term relationships with added value (Fairholm, 2000).

The executives communicate on the basis of their conception of Company A, a company that participates in a historical milestone and is socially responsible. In 2015, the new President to the country was elected, which became a historic milestone for executives. In the letters are phrases such as "Company A will continue to enhance its contribution to the development of Sri Lanka. That is the great task of this decade, which begins with the celebration of the new era "(Financial statement 2015, Company A). The reference to the Presidential Election is a way of communicating and clarifying the role that Company A has had as a public company in the country's development, through the generation of surpluses and the one that contributes the highest revenues to the nation's budget. However, the concept of historical milestone is not present in the company Company B.

The concept of responsible company is a basic conception of executives in their speech. This conception is inferred from the reference to the different actions that the executives say that the company carries out, from the social, cultural, economic, environmental and labor points of view. An analysis of the letters by the researcher showed that the assumptions made are mainly in the human resources dimension (18\%), then in the environmental dimension (16\%) and finally in the economic dimension $(13 \%)$.

From the analysis of the financial communication it can be inferred that the executives' discourse, which accompanies the presentation of Company A's financial statements, has a preferential national focus, since it emphasizes its contribution to the country's development; it is also a socially responsible company that engages and establishes a place in the country's history. Finally, a relationship is created with the strategic dimension of financial communication, a strategic and tactical weapon that allows the generation and diffusion of a desirable image before its target audience (Bompoint \& Marois, 2004).

In the case of the Company B, the managers communicate, first, from the conception they have of a socially responsible company and then from the concept of multinational company. An analysis of the letters by the researcher showed that the assumptions made are mainly based on the economic dimension 
$(30 \%)$, then on the environmental dimension (18\%) and lastly on the human resources dimension $(12 \%)$.

The allusion to the concept of socially responsible enterprise appears, preferably, in reference to the contribution the makes to the communities within its catchment area, which are mostly agrarian communities.

In the letters are phrases such as "in Sri Lanka the Company B foundation actively collaborated with the education of communities ... the education of our neighbors has become a moral and strategic imperative". Company B is a company belonging to the forestry industry and as such its directors are aware of the externalities generated by their activity in the environment, starting from the supply of raw materials. This requires the afforestation of territories that were originally used in agricultural production; at the same time, afforestation and subsequent felling of forests has an impact on small farms in neighboring communities, for example, after a few years of a forest plantation, water flows begin to decline due to an increase in the evapotranspiration rate. The protection of these territories is carried out by social pressure groups (e.g. environmentalists, indigenous people) while the Company $\mathrm{B}$ directors through the letters disseminate information to the national community, against the pressure of these social pressure groups.

Second, managers communicate from the conception of a multinational company, unlike the Company A, where it is not known whether the company has subsidiaries abroad. Company B's letters reveal judgments such as "overseas subsidiaries improve their results measured in dollars." "During 2015, significant progress was made in the international development projects of Company B Tissue, with the acquisition of the operations of the $\mathrm{X}$ Group." In both cases, the directors of Company B report that the company's performance has transcended the borders, and this information is addressed to the shareholders and potential investors of the company.

The directors of the Company B also contribute to national development from a socially responsible company role. The strategic dimension of financial communication is inferred, seeking to face the challenges that arise in its immediate surroundings, unlike the Company A.

Company B's financial communication also emphasizes the notion of multinational company and the success of investment projects outside national boundaries. In this sense, the marketing dimension of financial communication is related to the positioning of the company in the stock exchange, which seeks to positively influence the share price of the company.

\section{Role of financial communication}

From the analysis of the data, it is inferred that the objective of the discourse 
presented in the financial statements presentation sheets - issued by the Company A executives - is in the first place the projection and maintenance of a desired image of the executives: "The historic figures of these years surpassing US \$ XXX million in the period - reaffirm that Company A is Sri Lanka 's best business.... Company A is the most valued company by all citizens; second, to maintain power relations with the pressure groups, especially with the workers, which is reflected throughout the period under study with judgments such as "a word of thanks for the Company A workers, for their commitment and development of the company, since none of the resources generated for Sri Lanka in these years would have been possible without their participation"(Financial statement 2015, Company A).

Workers through their trade union organizations represent one of the most important social pressure groups. For them, the financial information of the company plays a fundamental role when carrying out the processes of collective bargaining. It can be inferred that the managers focus their attention on the maintenance of harmonious relations with the workers with the objective of reducing the financial impact of the collective demands of the workers, the accident rate and the possible work stoppages.

In Company A's case the projection and / or conservation of a desired image becomes a constant throughout the study period, for example, it can be read: "The foundations of our business are solid and we are optimistic to keep this path with a focused investment strategy."This image is projected mainly to the shareholders, seeking to maintain confidence levels in the economic group and, therefore, to promote the company as a product, whose value is reflected in the share price.

Likewise, the message that seeks to communicate its commitment to Sri Lankan society as a whole, mainly with social pressure groups, is reiterative. Information is provided on social responsibility projects carried out, for example, "The year 2014 was marked by the celebration of the $\mathrm{XX}^{\text {th }}$ anniversary of the company, which gave rise to various activities with the community (Financial statement 2014, Company B).

Undoubtedly, this information is not addressed to the Sri Lankan people as a whole, but to the shareholders, mainly, and social pressure groups (environmentalists and indigenous people), both interested in knowing the relationship between the company and its immediate surroundings, according to the interests of each group.

\subsection{Conclusions}

From the inductive analysis of the results obtained, we can infer and propose the following hypotheses: From the discursive point of view, the enunciators of the letters of communication of the financial statements of both companies communicate assertively with their addressees, becoming involved and committing them to the speech expressed. From the social point of view, the announcers of the letters of presentation of the financial statements of the company A establish in the communication, 
symmetrical power relations; on the contrary, in the case of Company B, it establishes asymmetric relations.

Through the speech presented by the chairman and / or general manager in the letters of presentation of the financial statements, the aim is to align the results obtained with the context that the company faces. The speech is mirrors the situations the company faces both within the country and abroad, which directly or indirectly affects the company. Thus, the articulation between the text and the social space where it is produced is confirmed.

Managers - through the financial statement presentation letters - expect to disseminate a desired organizational image as well as exerting influence on social pressure groups. For Company A executives, the focus is on workers, while for Company B is on neighboring communities. In this way, the strategic dimension of managerial discourse is established. On the other hand, for Company B managers' focus is also on investors, and to deliver favorable financial information in order to influence the share price; That is, the promotion of the company as a product to the stock market. Thus, the marketing dimension of managerial discourse is established, which seems delicate, especially in the context of private companies.

The ultimate goal of a private enterprise is usually expressed in terms of utility maximization, which often causes managers to deviate from the essential, that is, from productive processes; they have transformed the companies into "products" that are traded on the Stock Exchange. For managers what is important is how to influence the price of action, this has kept them away from the problems that occur in the operational core, which is what really interests the society as a whole.

Finally, it can be inferred that one of the roles of the managers of the organizations - public or private - is to exert influence, through the language, on a certain group of reference. This influence is due to a strategy put in place to position the interests of the organizations. Thus, through the discourse in the letters, it is intended to influence the thinking of the recipients, in the construction of their knowledge, accumulating experiences, allowing them to reiterate their experiences, recognizing them as identical, and finally becoming familiar with the business world. 


\section{References}

1. Berger, P. \& Luckmann, T. (1967). The social construction of reality: A treatise in the sociology of knowledge. New York: Anchor Books.

2. Bhatia, V. (2004) Worlds of Written Discourse: A Genre-Based View. Continuum, London.

3. Brandom, R. (2008). Between saying and doing: Towards an analytic pragmatism. Oxford: Oxford University Press.

4. Bruner, J. (1991). Acts of meaning. Cambridge: Harvard University Press.

5. Bruner, J. (1986). Actual minds, possible worlds. Cambridge: Harvard University Press.

6. Bruner, J. (2002). Making stories: Law, literature, life. New York: Farrar, Strauss and Giroux.

7. Castelló, M., Corcelles, A., Iñesta, G., Bañales, M. \& Vega, N. (2011). The author's voice in academic writing: A proposal for analysis. Signs 44, (76), 105-117.

8. Charaudeau, P. (1982). Elements of semio-linguistics from a theory of language to an analysis of discourse. Language in Situation: Practice social and interaction, (38), 6-28.

9. Charaudeau, P. \& Maingueneau,D. (2002). Dictionary of discourse analysis. Paris Edition.

10. Devi, R., Devi, J., Kumar, R \& Taylor, C. (2012). Accountant and user perceptions of Fair Value accounting: evidence from Fiji. Global Journal of Business Research, 6(3).

11. Halliday, M.A.K. \& Hasan, R. (1985). Language, Context and Text: a Social Semiotic Perspective. Deakin University Press.

12. Hatch, E. (1992). Discourse and Language Education. Cambridge University Press

13. Johnson, K. \& Johnson, H. (1999). ) The Encyclopedic Dictionary of Applied Linguistics: A Handbook for Language Teaching. Wiley.

14. Junhui, W. (2015). Studies of subjectivity in language. Studies in Literature and Language, $10(3), 73-76$.

15. Lämsä, A. and Sintonen, T. (2006). A narrative approach for organizational learning in a diverse organisation, Journal of Workplace Learning, 18 (2), 106-120, https:// doiorg/10.1108/13665620610647818

16. Lemoine, J.F. \& Onnée, S. (2003). Towards an analysis of the issues and practices of the management of the relationship with the individual shareholder. Marketing Decisions, (31), 25-37.

17. Lepsinger, R. \& DeRosa, D. (2010). Virtual Team Success: A Practical Guide for Working and Leading from a Distance. Wiley.

18. Simon, G. (2013). Relational Ethnography: Writing and Reading in Research Relationships. Qualitative Social Research, 14(1).

19. Manca, E. (2012). Context and language. University of Salento.

20. Levinson, C. S. (1983). Pragmatics. Cambridge University Press, Cambridge.

21. Malinowski B. (1994). The Problem of Meaning in Primitive Language. In J. Maybin(ed.), Language and Literacy in Social Practice: A Reader. Avon: The Open University Press, 1-10.

22. Sürmen, Y. \& Daştan, A. (2014). The development of accounting as a scientific discipline in Turkey. Inderscience, 6 (2).

23. Teun, A. (1993). Principles of critical discourse analysis. Discourse \& Society, 4(2), 249-283

24. Thomas, J. (2013). Meaning Interaction: an Introduction to Pragmatics. Routledge, New York

25. Weick, K. (1995). Sensemaking in Organizations. California: Sage Publications, London. 